\title{
Native Endophytic Pseudomonas putida as a Biocontrol Agent against Common Bean Rust Caused by Uromyces appendiculatus
}

\author{
Kamal A. M. Abo-Elyousr ${ }^{1, *(D)}$, Ismail R. Abdel-Rahim ${ }^{2} \mathbb{D}$, Najeeb M. Almasoudi ${ }^{1}$ and Sameera A. Alghamdi $^{3}$ \\ 1 Department of Arid Land Agriculture, Faculty of Meteorology, Environment and Arid Land Agriculture, \\ King Abdulaziz University, Jeddah 80208, Saudi Arabia; nalmasoudi@kau.edu.sa \\ 2 Botany and Microbiology Department, Faculty of Science, Assiut University, Assiut 71516, Egypt; \\ ismailramadan@aun.edu.eg \\ 3 Department of Biological Sciences, Faculty of Sciences, King Abdulaziz University, Jeddah 21551, \\ Saudi Arabia; saalghamdi17@gmail.com \\ * Correspondence: kaaboelyousr@agr.au.edu.eg; Tel.: +966-54-397547
}

check for updates

Citation: Abo-Elyousr, K.A.M.; Abdel-Rahim, I.R.; Almasoudi, N.M.; Alghamdi, S.A. Native Endophytic Pseudomonas putida as a Biocontrol Agent against Common Bean Rust Caused by Uromyces appendiculatus. J. Fungi 2021, 7, 745. https://doi.org/ 10.3390/jof7090745

Academic Editors: Susanne Zeilinger and Gary A. Strobel

Received: 10 August 2021

Accepted: 7 September 2021

Published: 10 September 2021

Publisher's Note: MDPI stays neutral with regard to jurisdictional claims in published maps and institutional affiliations.

Copyright: (C) 2021 by the authors. Licensee MDPI, Basel, Switzerland. This article is an open access article distributed under the terms and conditions of the Creative Commons Attribution (CC BY) license (https:// creativecommons.org/licenses/by/ $4.0 /)$.

\begin{abstract}
This study aimed to evaluate the efficacy of endophytic bacterium to control common bean rust disease under greenhouse conditions. Endophytic bacterium Pseudomonas putida ASU15 was isolated from fresh asymptomatic common bean, identified using biochemical and molecular characteristics. In vitro, the inhibitory effect of different concentrations of P. putida $\left(1 \times 10^{4}, 1 \times 10^{5}\right.$ and $\left.1 \times 10^{6}\right)$, as well as fungicide ortiva $(0.01 \%)$ on uredospores germination of Uromyces appendiculatus were tested using water agar medium. The concentration showing the highest reduction of uredospores germination was at $1 \times 10^{6}$, while there was complete inhibition of uredospores germination associated with using ortiva. Scanning electron microscope exhibited the ability of P. putida cells to attack the cell wall of the fungal uredospores germ tubes of $U$. appendiculatus, causing obvious cell wall breakdown. The activities of chitinase, lipase, and protease produced by P. putida ASU15, in vitro, were evaluated spectrophotometrically. Chitinolytic, proteolytic, and lipolytic activities were exhibited, contributing 55.26, 3.87, and $26.12 \mathrm{U} / \mathrm{mL}$, respectively. Under greenhouse conditions, treated plants with P. putida ASU15 (two days before pathogen inoculation or at the same time of pathogen inoculation) or fungicide reduced the disease severity, compared to the control. Applying P. putida ASU15 at the same time of pathogen inoculation showed reduction in disease severity (69.9\%), higher than application before pathogen inoculation $(54.9 \%)$. This study is considered the first report that demonstrates the mycoparasitic strategy of P. putida for controlling U. appendiculatus. In conclusion, our results revealed that P. putida ASU15 affords a significant disease reduction that may be attributed to direct suppression of pathogen spores germination.
\end{abstract}

Keywords: common bean; cell wall degrading enzymes; endophytes; Pseudomonas putida; Uromyces appendiculatus; rust disease

\section{Introduction}

Common bean (Phaseolus vulgaris L.) is one of the most important vegetable food legumes in Egypt for local consumption and exportation [1]. Bean rust, incited by Uromyces appendiculatus (Pers. Ex Pers.), is one of the most destructive, yield-limiting, worldwide diseases of common bean [2]. Economically, it causes yield losses ranging from 25 to 100\% in susceptible cultivars [3,4]. Interestingly, it has been reported as an economical threat to the dry beans in South Africa, producing 100\% losses for rust-susceptible varieties [5]. Indeed, bean rust was mainly managed using chemical fungicides [6]. The use of fungicides had been practiced and its success depends mainly on the high repetition of applications; however, fungicides were recently restricted in many countries for use against bean rust due to their adverse effects on non-target species, environmental pollution, and development 
of fungicide resistant strains, in addition to the harmful aspects they cause to humans and climate [7]. On the other hand, bean rust was sometimes controlled based on host resistance, but resistance has not been long-lasting due to the pathogen's high genetic diversity and ability to evolve new pathogen strains. Actually, the use of plant resistance is not only harmless to the environment but also an economically sound strategy, compared to chemical control. However, the wide variability of $U$. appendiculatus represents an obstacle to breeders aiming at the development of common bean cultivars with durable resistance to rust [8].

Biological control of rust on bean has been previously explored as an effective approach for disease management [9]. It has been reported as a nature-friendly alternative method due to their ability to antagonize the pathogen by different modes of action and to effectively colonize distinct plant habitats $[10,11]$. Endophytic bacteria have been reported as potent biological control agents of several plant pathogens [12]. Endophytic bacteria have been defined as those that colonize the internal tissue of the plant, showing no external sign of infection or negative effect on their host [13]. Endophytes have been isolated from various parts of the plants, including the leaves, flowers, stems roots, seeds, and fruits [14]. Some of these bacteria are beneficial for their hosts; they can also accelerate seedling emergence, promote plant establishment under adverse conditions [15], and enhance plant growth [16]. Bacterial endophytes have been shown to prevent disease development [17]. Endophytic bacteria, as plant growth promoters, assist in the uptake of essential nutrients [9], and produce essential phytohormones [18]. On the other hand, these bacteria support plant defense against phytopathogens by developing antibiotics [10], producing hydrogen cyanide [19], competing for nutrients with phytopathogens [20], and causing systemic resistance in the host [21].

Pseudomonas is considered one of the most characterized biocontrol plant growthpromoting bacteria [22]. Moreover, many species of Pseudomonas have several advantages for use as biological control agents. Pseudomonas putida has been reported as an effective biocontrol agent against several plant pathogens such as Rhizoctonia solani in cucumber [23], Fusarium oxysporum f.sp. radicis-lycopersici in tomato [24,25], $R$. solani in potato [26], Sclerotinia sclerotiorum in lettuce [25], Pectobacterium atrosepticum in potato [25], and Ralstonia solanacearum in tomato [27]. Indeed, most of the previous studies attributed potentiality of the diseases management by P. putida to antibiotics production, competition on nutrients and space, and induction of host systemic resistance.

To our knowledge, this is the first report of direct mycoparasitic potentiality of Pseudomonas putida as a mode of action for controlling Uromyces appendiculatus. Thus, the present study aimed to: (1) isolate and identify endophytic bacteria P. putida from common bean plants and (2) evaluate the efficacy of endophytic bacteria for controlling bean rust under greenhouse conditions.

\section{Materials and Methods}

\subsection{Source of Uromyces appendiculatus and Spores Collection and Preservation}

The uredospores of $U$. appendiculatus were obtained from naturally infected plants that were cultivated in El-Menia Governorate, Egypt. For multiplication of the amount of spores, the obtained uredospores were used to re-infect the plants growing under greenhouse conditions at Assiut University. Two healthy bean seeds cv. Giza 6 were sown in plastic pots $15 \mathrm{~cm}$ in diameter (1.4 kg soil), filled with a sterilized soil. The pots were kept in the greenhouse at temperatures ranging between 20 and $25^{\circ} \mathrm{C}$ and then the plants were fertilized when needed. The growing terminal bud of each plant was removed above the fourth or fifth leaf, to restrict the indeterminate growth of the cultivar, and to facilitate the handling of the plants [28]. Plants aged 25-days old were artificially inoculated by uredospores. To prepare the inoculum, uredospores were suspended in sterile distilled water and mixed with agar $(0.1 \mathrm{~g} / \mathrm{L})$ before inoculation. The inoculation was done by spraying the plants with a suspension of uredospores with an atomizer (complete leaf coverage). The inoculated plants were kept in darkness for $48 \mathrm{~h}$. Meanwhile, mature 
uredospores were collected from the leaves on aluminum foil and dried, then transferred to micro-tubes and stored under freezing conditions, for 15 days, until the following experiments.

\subsection{Isolation of Endophytic Strain ASU15}

Strain ASU15 was isolated, as endophytic bacteria, from fresh asymptomatic healthy leaves of common bean cultivated in Assiut Governorate (Egypt). The leaves samples were collected in sterilized polyethylene bags and immediately transferred to a microbiological laboratory. Bacterial isolation was carried out using a surface sterilization protocol described by Li et al. [29] and Abdelshafy et al. [30]. The samples of leaves were thoroughly washed under tap water and subsequently sterile distilled water to remove adhering debris and epiphytic microorganisms. The leaves were cut into small segments by using sterile scissors. Thereafter, the leaf segments were surface sterilized, under a laminar airflow cabinet, by soaking in $70 \%$ alcohol for $30 \mathrm{~s}$ with shaking, followed by immersion in a $2 \%$ aqueous solution of sodium hypochlorite for $2 \mathrm{~min}$. Then, they were rinsed with sterilized distilled water 3 times (for removing the residues of the chemical agents applied in the surface sterilization) and further dried in sterilized paper. One gram of the surfacesterilized leaf segments was crushed and macerated under sterile conditions in a sterilized mortar and $9 \mathrm{~mL}$ of sterile sodium phosphate buffered saline was added. The tissue juice was collected in sterile polypropylene tube, homogenized by vortex for $2 \mathrm{~min}$, and then centrifuged at $8000 \mathrm{rpm}$ for $5 \mathrm{~min}$. The supernatant was collected, serially diluted up to $10^{-4}$ using sterile $10 \mathrm{mM}$ sodium phosphate buffer, $\mathrm{pH}$ 7. Then, one milliliter of the finally diluted solution of intercellular fluid of leave tissue was plated on nutrient agar plates in triplicate and kept in an incubator at $28^{\circ} \mathrm{C}$ for $72 \mathrm{~h}$. The growing bacterial colonies were streaked, purified, and identified.

\subsection{Phenotypic Characterization of Endophytic Pseudomonas putida Strain ASU15}

Phenotypic characterization of the endophytic bacterium included cultural, morphological, microscopic, biochemical, and physiological quantifications following the classical tests described in Bergey's Manual of Systematic Bacteriology [31]. Circumstantially, we evaluated colony morphology, pigmentation, cell morphology, mobility, Gram staining, utilization of carbon sources, enzyme activity, and growth on different $\mathrm{pH}$ values and salinity.

\subsection{Genotypic Identification of Endophytic Pseudomonas putida Strain ASU15}

Bacterial DNA extraction was executed applying SDS/CTAB lysis and phenol/chloroform extraction technique. The extracted DNA was dissolved in $20 \mathrm{~mL}$ TE buffer and then used as a template for PCR. The universal primers set of 27F (5'-CAGAGTTTGATCCTGGCT-3') and 1492R (5'-AGGAGGTGATCCAGCCGCA-3') was selected for the amplification of $16 \mathrm{~S}$ rRNA gene. The amplification process was carried out in a $25 \mu \mathrm{L}$ reaction volume including 10-50 ng DNA template, $0.4 \mu \mathrm{M}$ of each primer, $0.75 \mathrm{U}$ EF-Taq DNA polymerase, $0.2 \mu \mathrm{M}$ of each dNTP, and 1EF-Taq reaction buffer. The kits, enzymes, and chemical ingredients used in DNA extraction, purification, and amplification were manufactured by SolGent Company (Daejeon, Korea). The thermocycling conditions of PCR were operated as the following: $15 \mathrm{~min}$ at $95{ }^{\circ} \mathrm{C}$ for initial denaturation step, followed by $20 \mathrm{~s}$ at $95{ }^{\circ} \mathrm{C}$ for 35 cycles of denaturation, $40 \mathrm{~s}$ at $50{ }^{\circ} \mathrm{C}$ for annealing, $1.5 \mathrm{~min}$ at $72{ }^{\circ} \mathrm{C}$ for extension and then $5 \mathrm{~min}$ at $72{ }^{\circ} \mathrm{C}$ for a final extension step. For separation of the PCR product, gel electrophoresis $(1.5 \%$ agarose having ethidium bromide plus a 0.5 Tris-acetate-EDTA (TAE) buffer) was applied. Moreover, the PCR product was visualized by a UV illuminator and then purified using a PCR purification kit. Sequencing of the PCR product was carried out using an ABI-Big Dye Terminator v3.1 cycle sequencing kit and an ABI 3730XL DNA analyzer (Applied Biosystems, Foster City, CA, USA). The obtained sequence of the 16S rRNA was analyzed using BLAST search program at the NCBI website: http:/ / blast.ncbi. nlm.nih.gov / Blast.cgi (accessed on 19 October 2020). On comparison to 16S rRNA gene 
sequences of many standard strains from GenBank, the alignment was estimated using the multiple sequence alignment program CLUSTALW. Moreover, the molecular phylogenetic tree was constructed using MegAlign (ver. 5.01).

\subsection{Determination of Suppressive Impact of Pseudomonas putida ASU15 on Uredospores Germination}

Under light microscope, determination of the inhibitory impact of P. putida strain ASU15 on germination of uredospores of $U$. appendiculatus was carried out according to methods described by Li et al. [32]. Fresh uredospores (150 spores) were uniformly spread on the surface of water agar with $100 \mu \mathrm{L}$ of P. putida strain ASU15 at different concentrations of $1 \times 10^{4}, 1 \times 10^{5}$, and $1 \times 10^{6} \mathrm{CFU} \mathrm{mL} \mathrm{mL}^{-1}$. For each treatment, germination of spores in five visual fields was examined under a light microscope. Examination of the germination of uredospores on water agar without bacterial treatment was used as control, while the treatment with $100 \mu \mathrm{L}$ of fungicide Ortiva $0.01 \%$ was used as the referenced treatment. All treatments were incubated at $19^{\circ} \mathrm{C}$ for $6 \mathrm{~h}$ and then germination of uredospores was examined via a light microscope. The experiment was a completely randomized design with three replicates for each treatment, and then the experiment was repeated twice.

\subsection{Scanning Electron Microscopy (SEM) Analysis}

The potentiality of P. putida strain ASU15 to attack germinated uredospores of Uromyces appendiculatus was investigated using SEM that was available at the electron microscope unit, Assiut University. The samples of uredospores treated with P. putida strain ASU15 were fixed in $4 \%$ cold gautaraldehyde and then rinsed using $\mathrm{C}_{2} \mathrm{H}_{6} \mathrm{AsNaO}_{2}$ buffer. The prepared specimens were subsequently dehydrated by applying a gradual increase in the rate of ethanol, dried in critical point drainer by liquid $\mathrm{CO}_{2}$, and then cemented on the metallic block. The specimens were uniformly gold coated at a thickness of $15 \mathrm{~nm}$ using gold splutter apparatus. Eventually, the specimens were examined and photographed using JSM 5400 LV Scanning Electron Microscope (JEOL Ltd., Tokyo, Japan). SEM was operated at an acceleration voltage of $15 \mathrm{kV}$ with magnification range $1000 \times-3500 \times$ and a $10 \mathrm{~mm}$ working distance under low vacuum.

\subsection{Evaluation of Extracellular Enzymatic Activities}

\subsubsection{Chitinase Activity}

Chitinolytic activity was essayed using the technique described by Chen and Lee [33]. P. putida strain ASU15 was firstly grown for $48 \mathrm{~h}$ at $25^{\circ} \mathrm{C}$ on a chitin-containing medium. This medium included (g/L) $6.9 \mathrm{NaH}_{2} \mathrm{PO}_{4}, 0.3 \mathrm{MgSO}_{4} \cdot 7 \mathrm{H}_{2} \mathrm{O}, 1.4\left(\mathrm{NH}_{4}\right)_{2} \mathrm{SO}_{4}, 10$ peptone, $2.0 \mathrm{KH}_{2} \mathrm{PO}_{4}$, and 1.0 colloidal chitin, whereby chitin was prepared by the $85 \% \mathrm{H}_{3} \mathrm{PO}_{4}$ acid hydrolysis technique [34]. In a test tube, the reaction mixture $(0.5 \mathrm{~mL}$ of culture filtrate and $1.0 \mathrm{~mL}$ of the prepared colloidal chitin) was incubated at $30{ }^{\circ} \mathrm{C}$ for $60 \mathrm{~min}$. Then the reaction was terminated using $1.0 \mathrm{~mL}$ potassium sodium tartrate reagent and $1.0 \mathrm{~mL}$ of dinitrosalicylic acid. Spectrophotometrically, the liberated N-acetylglucosamine (NAG) units were measured at $540 \mathrm{~nm}$ as an indicator of chitinase activity [35]. Chitinase activity unit $(\mathrm{U} / \mathrm{mL})$ point out to the amount of enzyme required to produce $1 \mu \mathrm{mol}$ of NAG $\min ^{-1}$. Three replicates were carried out.

\subsubsection{Protease Activity}

Inocula of P. putida strain ASU15 were aseptically transferred into Erlenmeyer flasks (250 mL) including $50 \mathrm{~mL}$ of sterilized Czapek-Dox medium provided with casein $(50 \mathrm{mg})$ as a substrate for protease production [36]. Enzyme activity was essayed using the technique reported by Folin and Ciocalteu [37]. The test tube containing the reaction mixture ( $1 \mathrm{~mL}$ of crude enzyme and $5 \mathrm{~mL}$ casein) was vortexed and incubated for $10 \mathrm{~min}$ at $30{ }^{\circ} \mathrm{C}$. The reaction was terminated using $5 \mathrm{~mL}$ trichloroacetic acid. Thereafter, $5 \mathrm{~mL}$ of $\mathrm{Na}_{2} \mathrm{CO}_{3}$ and $1 \mathrm{~mL}$ of Folin-Ciocalteu's reagent were added. Spectrophotometrically, the absorbance was determined at $660 \mathrm{~nm}$. The liberated amino acids were calculated using the standard 
curve of tyrosine. Protease activity unit $(\mathrm{U} / \mathrm{mL})$ was defined as the amount of enzyme required to liberate $1 \mu \mathrm{mol}$ of tyrosine $\min ^{-1}$. Protease activity was determined three times.

\subsubsection{Lipase Activity}

P. putida strain ASU15 was inoculated into Erlenmeyer conical flasks containing $100 \mathrm{~mL}$ of lipase production medium at $30^{\circ} \mathrm{C}$ under agitation (120 rpm) for 2 days. Lipase production medium containing $(\mathrm{g} / \mathrm{L}) \mathrm{NH}_{4} \mathrm{NO}_{3}, 1 ; \mathrm{ZnSO}_{4}, 0.005 ; \mathrm{K}_{2} \mathrm{HPO}_{4}, 1.5 ; \mathrm{MgSO}_{4}, 0.025$; $\mathrm{FeSO}_{4}, 0.015 ; \mathrm{CaCl}_{2}, 0.025$ and amended with $1 \mathrm{~mL}$ Tween 80 [38]. The bacterial biomass was eliminated using centrifugation at $80,000 \mathrm{rpm}$ for $30 \mathrm{~min}$ under cooling $\left(4^{\circ} \mathrm{C}\right)$ and therefore the supernatants included the crude enzyme used for determination of lipase activity. Lipase activity was assayed using p-nitrophenylpalmitate (pNPP), as reported by Prazeres et al. [39]. Illustratively, a mixture of $1.0 \mathrm{~mL}$ of pNPP, $0.5 \mathrm{~mL}$ Triss buffer $(100 \mathrm{mM}$, $\mathrm{pH} 7)$ and $1.0 \mathrm{~mL}$ crude enzyme was transferred into a tube and then the volume was finalized into $3 \mathrm{~mL}$ by sterilized distilled water. The mixture was incubated at $30^{\circ} \mathrm{C}$ for $30 \mathrm{~min}$. The reaction was terminated by adding isopropanol $(0.2 \mathrm{~mL})$. Spectrophotometrically, lipase activity was evaluated at $410 \mathrm{~nm}$. Lipase activity unit $(\mathrm{U} / \mathrm{mL})$ represents $\mu \mathrm{mol}$ pNPP $\operatorname{~min}^{-1}$ liberated by one milliliter of the bacterial crude enzyme under standard assay conditions. The result was represented by three replicates.

\subsubsection{Protein Assay}

In order to calculate the specific activity, the concentration of extracellular protein that originated in the crude enzyme was determined [40]. The concentration of protein was expressed as $\mathrm{mg} / \mathrm{mL}$. A standard curve was carried out using bovine serum albumin. Three replicates were carried out. Eventually, the enzymatic specific activity was represented as $\mu$ mol liberated monomers per mg protein per min.

\subsection{Efficacy of Bacterium Isolate as Spraying Treatments for Controlling Common Bean Rust} Disease under Greenhouse Conditions

2.8.1. Inoculum Preparation, Inoculation Methods, and Evaluation of Disease Severity

The preserved uredospores were suspended in distilled water, followed by adding agar $(0.1 \mathrm{~g} / \mathrm{L})$ and then thoroughly mixing before inoculation of the plants [41]. The concentration of spores was measured using a hemocytometer and adjusted to the desired concentration $\left(1 \times 10^{6}\right.$ spores $\left./ \mathrm{mL}\right)$ by the dilution method, as mentioned by Lopes and Berger [28]. Two healthy bean seeds Giz 6 cultivar were sown in each pot and after 15 days, the plants were inoculated with uredospores suspension, as mentioned above. Inoculation was done by spraying using an atomizer, whereas the plant leaves were completely covered with the spore suspension of $U$. appendiculatus. Plants were placed in a dark highly humid chamber (humidity $>90 \%, 22{ }^{\circ} \mathrm{C}$ ). Plants sprayed only with water were used as control (healthy plants). Each treatment contained three replicates (three pots/treatment).

Disease incidence on the primary leaves of each plant was estimated. The disease severity was measured after 12-15 days of inoculation, according to the scale adopted for new procedures of the international classification [3]. This scale categorized the infection into six degrees: (1) no pustules; (2) necrotic spots without sporulation; (3) sporulating pustules with a diameter of $<300 \mu \mathrm{m}$; (4) sporulating pustules with a diameter ranging between 300-499 $\mu \mathrm{m}$; (5) sporulating pustules with a diameter ranging between 500-800 $\mu \mathrm{m}$; and (6) sporulating pustules with a diameter of $>800 \mu \mathrm{m}$.

2.8.2. Determination of Suppressive Impact of P. putida ASU15 on Incidence of Common Bean Rust

Under greenhouse conditions, the effect of spraying P. putida ASU15 and fungicide $0.01 \%$ Ortiva on incidence of common bean rust was evaluated. The bacterial suspension of $10^{6} \mathrm{CFU} / \mathrm{mL}$ was applied at two different times (two days before pathogen inoculation or at the same time of pathogen inoculation). After 15 days of pathogen inoculation, numbers and sizes of the pustules were determined and subsequently disease severity was 
calculated. The control plants were sprayed only with the pathogen. Three replicates were used for each treatment.

\subsection{Statistical Analysis}

The results were statistically analyzed via one-way ANOVA on the SPSS 10.0 (SPSS, Chicago, IL, USA) software program. On the other hand, results of the disease incidence under greenhouse conditions were analyzed based on two-way ANOVA. The mean as well as standard errors were computed for three replicates. Means were compared by Duncan's multiple tests and the statistical significance was determined at the $5 \%$ level.

\section{Results}

\subsection{Source of Uromyces appendiculatus}

The uredospores of $U$. appendiculatus were obtained from heavily infected bean plants in El-Menia Governorate, Egypt. Interestingly, rust-infected common bean plants in the field showed typical symptoms of the disease (Figure 1). Numerous reddish brown circular pustules of 1-2 $\mathrm{mm}$ in diameter, representing uredial lesions, develop on the upper and lower sides of bean leaves. Moreover, infected tissues of the leaves surrounding single large or small groups of uredial lesions turn yellow. The pustules rupture and liberate reddish brown uredospores. We collected the uredospores from uredial lesions of the naturally infected bean leaves and used them to re-infect bean plants cultivated in the greenhouse of Assiut University. The pathogenicity test exhibited the ability of $U$. appendiculatus spores to aggressively infect the plants, producing intensive symptoms of the disease (Figure 1).

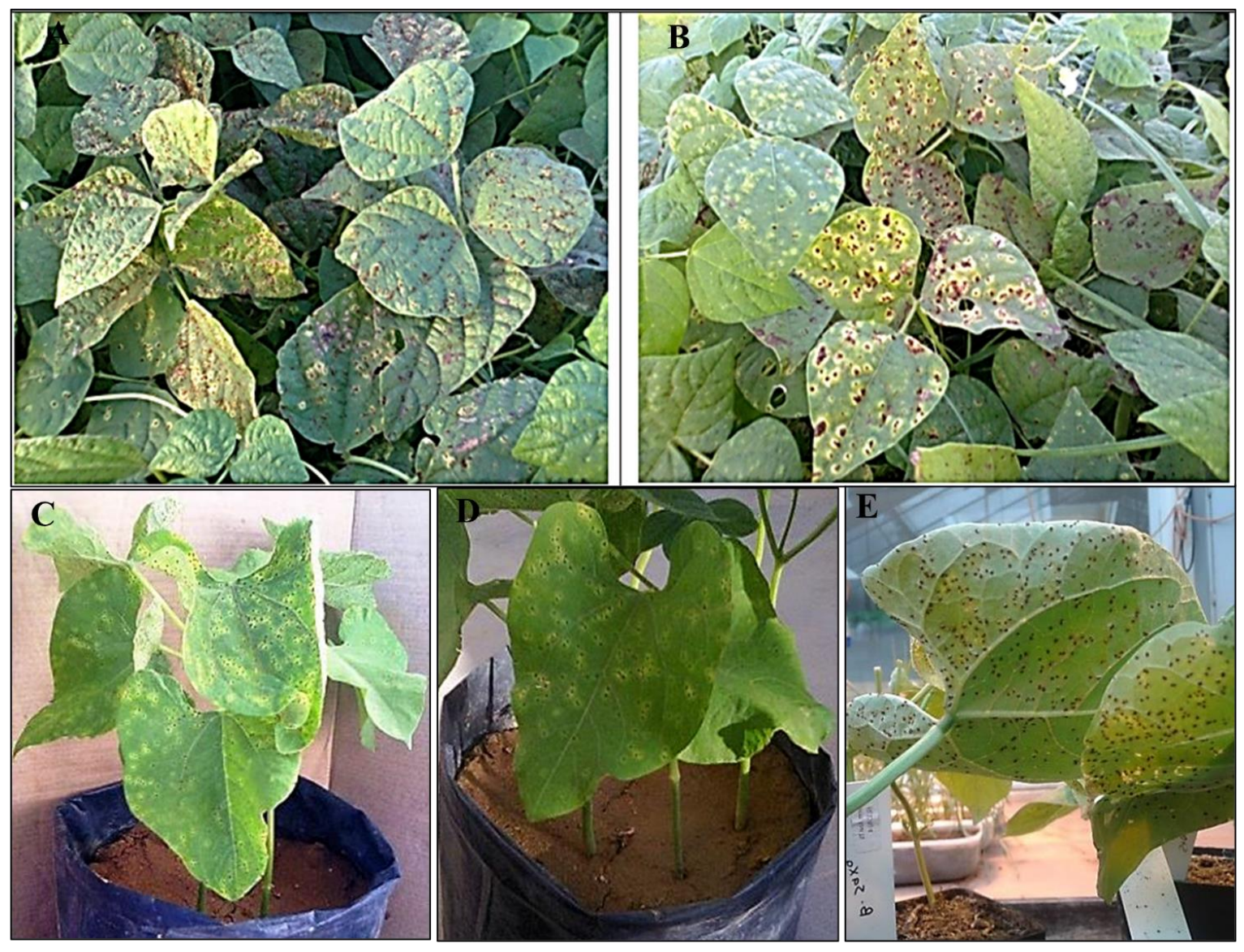

Figure 1. Common bean rust disease caused by Uromyces appendiculatus. (A,B) Naturally infected plants showing the symptoms of the rust disease; (C-E) Pathogenicity test exhibiting the ability of uredospores to re-infect the plants under greenhouse conditions. Developing of uredial lesions on the upper (C,D) and lower epidermis (E) of bean leaves. 


\subsection{Identification of Endophytic Bacterium}

In this study, Pseudomonas putida strain ASU15 was isolated as endophytic bacterium, from healthy leaves of common bean cultivated in Assiut Governorate (Egypt). The bacterial isolate was preliminarily identified at the level of genus Pseudomonas, depending on colony morphology, microscopic characteristics, as well as biochemical and physiological activities (Table 1). The bacterial colony was entire, circular, convex, and translucent with smooth surface, fluorescent, yellowish and 2-3 mm diameter on the isolation medium at $28^{\circ} \mathrm{C}$ after $48 \mathrm{~h}$ incubation. The bacterial cells were aerobic (unable to ferment glucose), Gram negative, single, motile small rods, $0.6-0.81 .2-1.8 \mu \mathrm{m}$. It was positive for catalase, gelatin hydrolysis, cytochrome oxidase, arabinose, dextrose, fructose, galactose, mannitol, mannose, indole, casein, xylose and utilization of glucose, orgnic acids (citric, galacturonic, gluconic, glucuronic, capric acids), and indole production. On the other hand, it was negative for starch and $\mathrm{H}_{2} \mathrm{~S}$ production, cellobiose, inositol, inulin, lactose, maltose, raffinose, rhamnose and sorbitol (Table 1).

Table 1. Morphological characteristics, physiological, and biochemical tests for characterization and identification of the endophytic bacterium Pseudomonas putida strain ASU15.

\begin{tabular}{|c|c|c|c|}
\hline Characteristics and Tests & Results & Characteristics and Tests & Results \\
\hline \multicolumn{4}{|c|}{ Morphological characteristics } \\
\hline Colony morphology & $\begin{array}{c}\text { Circular, convex and } \\
\text { translucent }\end{array}$ & Colony color & Yellowish \\
\hline Colony surface & Smooth & Colony margin & Entire \\
\hline Colony diameter & $2-3 \mathrm{~mm}$ & Fluorescent & + \\
\hline Cell shape & Short rods & Motility & + \\
\hline Gram Stain & Gram-ve & Spore formation & - \\
\hline \multicolumn{4}{|c|}{ The growth and utilization of different carbon sources } \\
\hline Glucose & + & D-Galacturonic acid & + \\
\hline Mannose & + & D-Gluconic acid & + \\
\hline Fructose & + & D-Glucuronic acid & + \\
\hline Galactose & + & Methyl Pyruvate & + \\
\hline Maltose & - & L-Lactic acid & + \\
\hline Raffinose & - & Citric acid & + \\
\hline Xylose & + & D-Malic acid & - \\
\hline Cellobiose & - & L-Malic acid & + \\
\hline Sucrose & - & Acetoacetic acid & - \\
\hline Lactose & - & Propionic acid & + \\
\hline Melibiose & + & Acetic acid & + \\
\hline L-arabinose & + & Formic acid & + \\
\hline Rhamnose & - & Tween 40 & + \\
\hline Inulin & - & D-Serine & - \\
\hline Dextrose & + & L-Serine & + \\
\hline Inosine & + & L-Alanine & + \\
\hline Gelatin & + & L-Arginine & + \\
\hline Pectin & - & D-Aspartic acid & - \\
\hline Sorbitol & - & L-Aspartic acid & + \\
\hline Mannitol & + & L-Glutamic acid & + \\
\hline D-Arabitol & - & L-Pyroglutamic acid & + \\
\hline Glycerol & - & Inositol & - \\
\hline Growth at $\mathrm{pH} 5$ & + & Sodium butyrate & + \\
\hline Growth at pH 6 & + & Sodium bromate & - \\
\hline Growth at $1 \% \mathrm{NaCl}$ & + & $1 \%$ Sodium lactate & + \\
\hline Growth at $4 \% \mathrm{NaCl}$ & + & & \\
\hline Growth at $8 \% \mathrm{NaCl}$ & - & & \\
\hline \multicolumn{4}{|c|}{ Physiological and enzymatic activities } \\
\hline Glucose fermentation & - & Casein hydrolysis & + \\
\hline Cellulase & - & Starch hydrolysis & - \\
\hline Catalase & + & $\mathrm{HCN}$ production & - \\
\hline Oxidase & + & $\mathrm{H}_{2} \mathrm{~S}$ production & - \\
\hline Urease & + & Nitrate reduction & + \\
\hline Indole acetic acid & + & & \\
\hline
\end{tabular}

The results of 16S rRNA analysis and gene sequences (1061 base pair) of our indigenous bacterium Pseudomonas strain ASU15 showed 99.81\% similarity to P. putida strain F50 (MT271890). The 16S rRNA sequence of P. putida strain ASU15 was deposited into GenBank 
under accession number MW186768. A phylogenetic tree was estimated with other closely related neighboring sequences of different referential strains at GenBank (Figure 2).

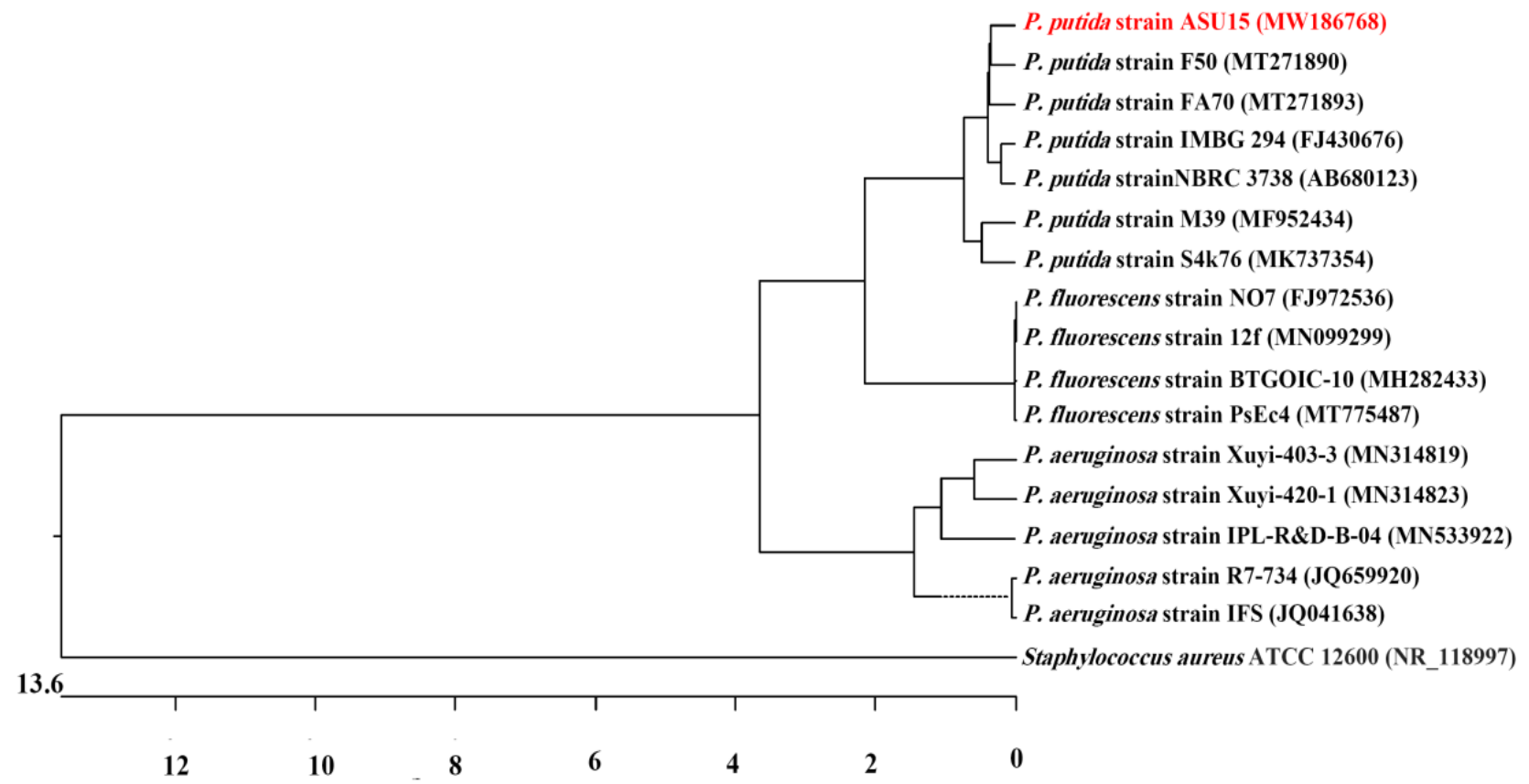

Nucleotide Substitutions $(\times 100)$

Figure 2. Molecular phylogenetic tree of $16 \mathrm{~S}$ rRNA gene sequence of Pseudomonas putida strain ASU15 (red font) with related referential bacterial strains in GenBank database were constructed by the Neighbor-Joining method using MegAlign software (ver. 5.01). Staphylococcus aureus strain ATCC 12,600 (NR_118997) was used as an out-group. Accession numbers of the National Center for Biotechnology Information (NCBI) database of each strain are given in brackets.

\subsection{Inhibitory Impact of P. putida ASU15 on Germination Rate of Uredospores}

The results presented in Table 2 revealed that the applying of P. putida ASU15 significantly inhibited the germination rate of urediniospore. Moreover, the rate of uredospores germination was reduced with increase in bacterial concentration. The germination rates of the urediniospore treated with P. putida ASU15 $1 \times 10^{4}, 1 \times 10^{5}$, and $1 \times 10^{6} \mathrm{CFU}$ $\mathrm{mL}^{-1}$ were $16.00,11.33$, and $4.67 \%$, respectively, corresponding to inhibition rates of 83.89 , 88.59 , and $95.30 \%$, respectively (Table 2). The rate of uredospores germination on control was $99.33 \%$, while the use of fungicide Ortiva $(0.01 \%)$ showed complete inhibition of uredospores germination.

Table 2. Inhibitory impact of Pseudomonas putida strain ASU15 on germination rate of uredospores of Uromyces appendiculatus.

\begin{tabular}{ccc}
\hline Treatments (Concentration) & Germination Rate & \% Inhibition \\
\hline P. putida $\left(10 \times 10^{3} \mathrm{CFU} \mathrm{mL}^{-1}\right)$ & $16.00 \pm 1.30^{\mathrm{b}}$ & 83.89 \\
P. putida $\left(10 \times 10^{5} \mathrm{CFU} \mathrm{mL}^{-1}\right)$ & $11.33 \pm 1.60^{\mathrm{c}}$ & 88.59 \\
P. putida $\left(10 \times 10^{6} \mathrm{CFU} \mathrm{mL}^{-1}\right)$ & $4.67 \pm 1.20^{\mathrm{d}}$ & 95.30 \\
Fungicide Ortiva $\left(0.01^{\mathrm{d}}\right)$ & $0.00 \pm 0.00^{\mathrm{e}}$ & 100.00 \\
Control & $99.33 \pm 0.88^{\mathrm{a}}$ &
\end{tabular}

Numbers within column are means \pm standard deviations of three replicates. Values within column that associate with different letters indicate significant differences $(p \leq 0.05)$ based on one-way ANOVA analysis. The data are the means of more than 150 spores in five visual fields under light microscope in each treatment with three replications. 


\subsection{Scanning Electron Microscopy (SEM) Analysis}

Figure 3 exhibited an illustrative picture of the establishment of antagonistic activity of P. putida on germ tube of uredospores of $U$. appendiculatus (Figure 3). Preliminary, P. putida cells were in close contact with the germ tube's cell wall of uredospores for an attack. Lytic enzymes produced by P. putida degraded the cell wall of the germ tubes. Subsequently, a ruptured germ tube allowed to release the internal cytoplasmic contents. Thereafter, $P$. putida caused distinct deformation of the germ tube, compared with the non-treated one.
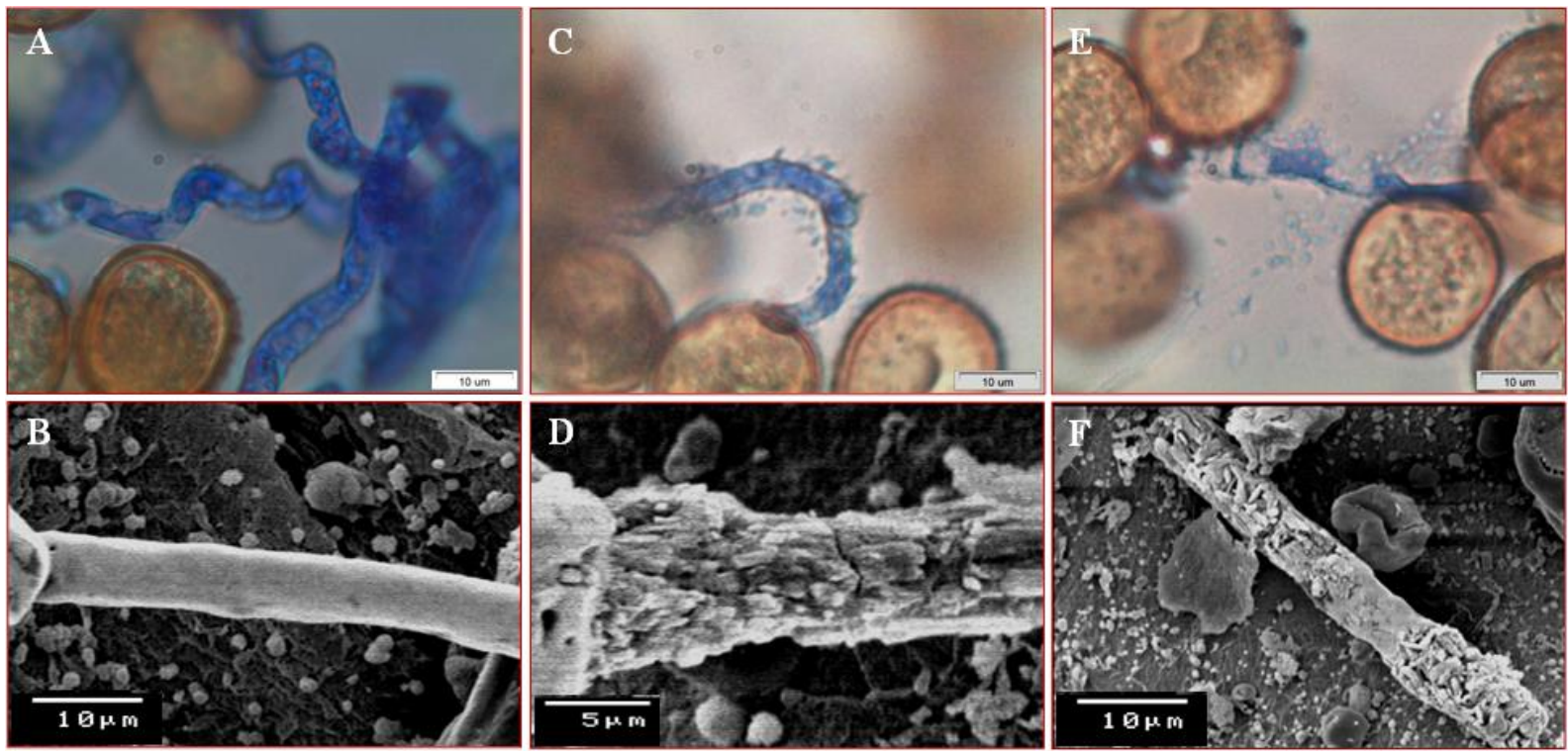

Figure 3. Light and scanning electron micrographs showing the inhibitory impact of Pseudomonas putida strain ASU15on uredospores of Uromyces appendiculatus. (A,B) Normal germinating uredospores (control) showing vigor germ tube; (C,D) $P$. putida cells attack the germ tube; (E,F) Degradation of cell wall of the germ tube by mycoparasitic activity of $P$. putida and then release of the cytoplasmic contents from a ruptured germ tube.

\subsection{Extracellular Enzymatic Activity}

The results presented in Table 3 indicated that the endophytic bacterium P. putida strain ASU15 has the potential to secrete various enzymes that play an important role in the decaying and distortion of the fungal pathogen. The activities of chitinolytic, lipolytic, and proteolytic enzymes produced by P. putida strain ASU15 were evaluated spectrophotometrically in vitro. The P. putida strain ASU15 exhibited chitinase activity $55.26 \mathrm{U} / \mathrm{mL}$ with a specific activity up to $8.96 \mathrm{U} / \mathrm{mg}$ proteins. The proteolytic activity was $3.87 \mathrm{U} / \mathrm{mL}$, corresponding to a specific activity of $8.41 \mathrm{U} / \mathrm{mg}$ proteins, while lipase activity amounted to $26.12 \mathrm{U} / \mathrm{mL}$, which was equivalent to a specific activity of $9.20 \mathrm{U} / \mathrm{mg}$ protein (Table 3).

Table 3. Evaluation of the enzymatic activities of endophytic bacterium Pseudomonas putida strain ASU15.

\begin{tabular}{cccc}
\hline Extracellular Enzymes & Chitinase & Lipase & Protease \\
\hline Enzymatic activity (U/mL) & $55.26 \pm 0.03$ & $26.12 \pm 0.02$ & $3.87 \pm 0.03$ \\
Protein $(\mathrm{mg} / \mathrm{mL})$ & $6.17 \pm 0.04$ & $2.84 \pm 0.02$ & $0.46 \pm 0.04$ \\
Specific activity (U/mg protein) & $8.96 \pm 0.20$ & $9.20 \pm 0.20$ & $8.41 \pm 0.12$ \\
\hline
\end{tabular}

Units of the enzymatic activity $(\mathrm{U})$ were expressed as follows: $\mu \mathrm{mol} N$-acetylglucosamine $\min ^{-1}$ for chitinase, $\mu \mathrm{mol} \mathrm{pNPP} \min ^{-1}$ for lipase, and $\mu \mathrm{mol}$ of tyrosine $\mathrm{min}^{-1}$ for protease. 


\subsection{Suppressive Impact of P. putida ASU15 on Incidence of Common Bean Rust}

Table 4 presented the inhibitory effect of Pseudomonas putida strain ASU15, as a foliar treatment, on disease severity of common bean rust under greenhouse conditions. Application of P. putida ASU1 $\left(10^{6}\right)$ at different times (two days before the pathogen inoculation or at the same time of the pathogen inoculation) as well as fungicide reduced disease severity, compared to the control treatment. The highest reduction was achieved by the fungicide (Ortiva $0.01 \%$ ), contributing 93\%. Treated plants with P. putida strain ASU15, at the same time of the pathogen inoculation, showed reduction in disease severity $(69.9 \%)$, higher than application two days before pathogen inoculation (54.9).

Table 4. Inhibitory effect of Pseudomonas putida strain ASU15, as a foliar treatment, on disease severity of common bean rust under greenhouse conditions.

\begin{tabular}{|c|c|c|c|c|c|}
\hline \multirow{2}{*}{ Treatments } & \multicolumn{2}{|c|}{$\begin{array}{l}\text { Two Days before the Pathogen } \\
\text { Inoculation }\end{array}$} & \multicolumn{2}{|c|}{$\begin{array}{l}\text { At the Same Time of Pathogen } \\
\text { Inoculation }\end{array}$} & \multirow{2}{*}{ Mean } \\
\hline & Severity & Reduction \% & Severity & Reduction \% & \\
\hline P. putida ASU15 & $26.67^{b}$ & 69.9 & $21.67^{b}$ & 54.8 & $31.67^{b}$ \\
\hline Ortiva & $5.00^{\mathrm{c}}$ & 93 & $5.00^{\mathrm{c}}$ & 92.9 & $5.00^{c}$ \\
\hline Control & $70.83^{a}$ & - & $71.67^{a}$ & - & $70.00^{\mathrm{a}}$ \\
\hline
\end{tabular}

Values within the column that associate with different letters indicate significant differences $(p \leq 0.05)$ based on two-way ANOVA analysis.

\section{Discussion}

In the current study, Pseudomonas sp. was identified, as the endophytic bacterium isolated from healthy bean plants, based on colony morphology, microscopic characteristics, and biochemical tests. Then, identification was confirmed at the molecular level using $16 \mathrm{~S}$ rRNA gene sequences. Genotypic identification of the Pseudomonas strain ASU15 was related to P. putida strain F50 (MT271890). This bacterium could be isolated as endophytic bacteria from the roots of plant species such as lemon and cotton [42,43], beet [44], and wheat cultivars [45]. Endophytic bacteria Bacillus sp. and Pseudomonas sp can be isolated from different plant species [46]. The phylogenetic analyses were carried out based on $16 \mathrm{~S}$ rRNA gene sequences, which are considered as core 'housekeeping' genes of bacteria and used as key evidence for bacterial identification [47].

In vitro, the obtained results showed that P. putida ASU15 was able to inhibit the germination rate of urediniospore of $U$. appendiculatus by increasing the bacterial concentration. The highest reduction of urediniospore was at $1 \times 10^{6} \mathrm{CFU} \mathrm{mL}{ }^{-1}$. These results are in accordance with those obtained by Abeysinghe [48], who mentioned that the use of rhizobcateria isolated from bean plant can reduce the germination of $U$. appendiculatu. Pseudomonas putida P286 reduced the urediniospore germination of Hemileia vastatrix [49].

Light and scanning electron microscope examinations of uredospores with antagonistic bacterium exhibited abnormalities, lysis, collapse, and shrinking as a direct effect of the P. putida. Our results mentioned that the pathogen was inhibited during spore germination. Only free water and leaf topography are linked to the pathogen's pre-penetration structure [50]. Based on this, the P. putida P286 isolate generated an antifungal compound that prevented the germination of uredospores [49]. The Pseudomonas species are recognized plant disease biocontrol agents. Production of antimicrobial compounds is one of the mechanisms associated with the antagonistic effect of these species [51]. Rajendran and Samiyappan [52] noted that using endophytic bacteria as whole cells can suppress some plant pathogenic fungi due to antimicrobial compounds that cause structural architect changes and lysis of mycelia [53].

In this study, the tested bacterial endophytes P. putida strain ASU15 produced chitinase, lipase, and protease. Endophytic microbes produce a variety of hydrolytic enzymes such as chitinase, lipase, and protease [54] that promote plant growth and preserve it from phytopathogens [55]. Hydrolytic enzymes can enhance plant growth by hydrolyzing 
phytopathogen cell walls [56]. Chitinase activities can hydrolyze chitin in the fungal cell wall, which leads to control of phytopathogenic fungi and promotes plant growth [57]. Hallmann Hallmann et al. [58] mentioned that the extracellular enzymatic activities of endophytic microbes could improve the induced systematic resistance in the plant.

Under greenhouse conditions, applying P. putida ASU15 two days or at the same time of inoculation with $U$. appendiculatus reduced the disease severity of bean rust disease compared with the control. Treating plants with bacteria at the same time of inoculation showed higher reduction in disease severity than application before inoculation. Endophytic bacteria have been used to control a wide range of pathogens [59]. Fouda et al. [60] reported that the highest concentration of bacteria leads to an increase in disease control. The antifungal substance produced by the antagonist bacteria was responsible for disease control-there is a strong correlation between antagonist concentrations and disease control. Antibiotics and volatile organic antifungal and antiviral compounds are among the secondary metabolic products generated by Pseudomonas $[37,49,50]$ that affect plant pathogens.

\section{Conclusions}

In conclusion, our results showed that P. putida (ASU15) afforded a strong reduction of spore germination of $U$. appendiculatus in vitro and a high reduction in the development of rust severity in vivo. Under greenhouse conditions, treatments with ASU15 and fungicide reduce disease severity compared to the control treatment-the highest reduction was achieved by Ortives, fungicide $0.01 \%$ 93\%, followed by ASU15 54.9-69.9\%.

Author Contributions: K.A.M.A.-E. and I.R.A.-R. suggested the idea of the work and contributed to data curation and validation, as well as writing the original draft and contributing to the formal analysis of the data. N.M.A. and S.A.A. contributed to the reviewing and editing of the manuscript. All authors have read and agreed to the published version of the manuscript.

Funding: This research work was funded by an institutional fund project under grant no (IFPHI-347155-2020).

Institutional Review Board Statement: Not applicable.

Informed Consent Statement: Not applicable.

Data Availability Statement: Not applicable.

Acknowledgments: This research work was funded by an institutional fund project under grant no (IFPHI-347-155-2020). Authors gratefully acknowledge technical and financial support from the Ministry of Education and King Abdulaziz University, DSR, Jeddah, Saudi Arabia.

Conflicts of Interest: The authors declare no conflict of interest.

\section{References}

1. Schwartz, H.F.; Corrales, M.A.P.; Centro Internacional de Agricultura Tropical (CIAT). Bean Production Problems in the Tropics; Centro Internacional de Agricultura Tropical (CIAT): Palmira, Colombia, 1989.

2. El-Fawy, M.M.; Abo-Elyousr, K.A.M. Efficacy of certain chemical compounds on common bean rust disease. Arch. Phytopathol. Plant Prot. 2016, 49, 522-532. [CrossRef]

3. Steadman, J.; Pastor-Corrales, M.; Beaver, J. An overview of the 3rd bean rust and 2nd bean common bacterial blight international workshops, 4-8 March 2002, Pietermaritzburg, South Africa. Annu. Rep. Bean Improv. Coop. 2002, 45, 120-124.

4. Acevedo, M.; Steadman, J.R.; Rosas, J.C. Uromyces appendiculatus in Honduras: Pathogen diversity and host resistance screening. Plant Dis. 2012, 97, 652-661. [CrossRef]

5. Jochua, C.; Amane, M.I.V.; Steadman, J.R.; Xue, X.; Eskridge, K.M. Virulence diversity of the common bean rust pathogen within and among individual bean fields and development of sampling strategies. Plant Dis. 2008, 92, 401-408. [CrossRef]

6. Ismail, A.M.; Afifi, M.M. Efficacy of some biotic and abiotic factors in controlling common bean rust disease caused by Uromyces appendiculatus. Egypt. J. Phytopathol. 2019, 47, 313-329. [CrossRef]

7. Ahmed, M.S.; Sallam, N.M.A.; Mohamed, A.A.; Hassan, M.H.A. Effect of mycorrhiza and biofertilisers on reducing the incidence of Fusarium root and pod rot diseases of peanut. Arch. Phytopathol. Plant Prot. 2013, 46, 868-881. [CrossRef]

8. Souza, T.L.P.; Faleiro, F.G.; Dessaune, S.N.; Paula-Junior, T.J.d.; Moreira, M.A.; Barros, E.G.d. Breeding for common bean (Phaseolus vulgaris L.) rust resistance in Brazil. Trop. Plant Pathol. 2013, 38, 361-374. [CrossRef] 
9. Yuen, G.Y.; Steadman, J.R.; Lindgren, D.T.; Schaff, D.; Jochum, C. Bean rust biological control using bacterial agents. Crop. Prot. 2001, 20, 395-402. [CrossRef]

10. Raaijmakers, J.M.; Vlami, M.; De Souza, J.T. Antibiotic production by bacterial biocontrol agents. Antonie Leeuwenhoek 2002, 81, 537. [CrossRef]

11. Sallam, N.A.; Riad, S.N.; Mohamed, M.S.; El-eslam, A.S. Formulations of Bacillus spp. and Pseudomonas fluorescens for biocontrol of cantaloupe root rot caused by Fusarium Solani. J. Plant Prot. Res. 2013, 53, 295-300.

12. Lodewyckx, C.; Vangronsveld, J.; Porteous, F.; Moore, E.R.; Taghavi, S.; Mezgeay, M.; Der Lelie, D.V. Endophytic bacteria and their potential applications. Crit. Rev. Plant Sci. 2002, 21, 583-606. [CrossRef]

13. Santoyo, G.; Moreno-Hagelsieb, G.; Del Carmen Orozco-Mosqueda, M.; Glick, B.R. Plant growth-promoting bacterial endophytes. Microbiol. Res. 2016, 183, 92-99. [CrossRef] [PubMed]

14. Lodewyckx, C.; Mergeay, M.; Vangronsveld, J.; Clijsters, H.; Van Der Lelie, D. Isolation, characterization, and identification of bacteria associated with the zinc hyperaccumulator Thlaspi caerulescens subsp. calaminaria. Int. J. Phytoremediation 2002, 4, 101-115. [CrossRef]

15. Chanway, C. Inoculation of tree roots with plant growth promoting soil bacteria: An emerging technology for reforestation. For. Sci. 1997, 43, 99-112.

16. Bent, E.; Chanway, C.P. The growth-promoting effects of a bacterial endophyte on lodgepole pine are partially inhibited by the presence of other rhizobacteria. Can. J. Microbiol. 1998, 44, 980-988. [CrossRef]

17. Strobel, G.; Daisy, B.; Castillo, U.; Harper, J. Natural products from endophytic microorganisms. J. Nat. Prod. 2004, 67, 257-268. [CrossRef]

18. Zaidi, A.; Ahmad, E.; Khan, M.S.; Saif, S.; Rizvi, A. Role of plant growth promoting rhizobacteria in sustainable production of vegetables: Current perspective. Sci. Hortic. 2015, 193, 231-239. [CrossRef]

19. Abo-Elyousr, K.A.; Bagy, H.M.K.; Hashem, M.; Alamri, S.A.; Mostafa, Y.S. Biological control of the tomato wilt caused by Clavibacter michiganensis subsp. michiganensis using formulated plant growth-promoting bacteria. Egypt. J. Biol. Pest Control 2019, 29, 54. [CrossRef]

20. Barahona, E.; Navazo, A.; Martínez-Granero, F.; Zea-Bonilla, T.; Pérez-Jiménez, R.M.; Martín, M.; Rivilla, R. Pseudomonas fluorescens F113 mutant with enhanced competitive colonization ability and improved biocontrol activity against fungal root pathogens. Appl. Environ. Microbiol. 2011, 77, 5412-5419. [CrossRef]

21. Mohamed, B.F.; Sallam, N.M.; Alamri, S.A.; Abo-Elyousr, K.A.; Mostafa, Y.S.; Hashem, M. Approving the biocontrol method of potato wilt caused by Ralstonia solanacearum (Smith) using Enterobacter cloacae PS14 and Trichoderma asperellum T34. Egypt. J. Biol. Pest Control 2020, 30, 1-13. [CrossRef]

22. Panpatte, D.G.; Jhala, Y.K.; Shelat, H.N.; Vyas, R.V. Pseudomonas fluorescens: A promising biocontrol agent and PGPR for sustainable agriculture. In Microbial Inoculants in Sustainable Agricultural Productivity; Springer: Berlin/Heidelberg, Germany, 2016; pp. 257-270.

23. Ohno, M.; Kataoka, S.; Numata, S.; Yamamoto-Tamura, K.; Fujii, T.; Nakajima, M.; Akutsu, K.; Hasebe, A. Biological control of Rhizoctonia damping-off of cucumber by a transformed Pseudomonas putida strain expressing a chitinase from a marine bacterium. Jpn. Agric. Res. Q. JARQ 2011, 45, 91-98. [CrossRef]

24. Lee, S.-W.; Ahn, I.-P.; Lim, J.-W.; Lee, Y.-H. Pseudomonas putida strain 17 Isolated from replant soil promotes tomato growth and Inhibits conidial germination of soilborne plant pathogens. Plant Pathol. J. 2005, 21, 244-251. [CrossRef]

25. Oliver, C.; Hernández, I.; Caminal, M.; Lara, J.M.; Fernàndez, C. Pseudomonas putida strain B2017 produced as technical grade active ingredient controls fungal and bacterial crop diseases. Biocontrol Sci. Technol. 2019, 29, 1053-1068. [CrossRef]

26. Andreote, F.D.; De Araújo, W.L.; De Azevedo, J.L.; Van Elsas, J.D.; Da Rocha, U.N.; Van Overbeek, L.S. Endophytic colonization of potato (Solanum tuberosum L.) by a novel competent bacterial endophyte, Pseudomonas putida strain P9, and its effect on associated bacterial communities. Appl. Environ. Microbiol. 2009, 75, 3396-3406. [CrossRef] [PubMed]

27. Sun, D.; Zhuo, T.; Hu, X.; Fan, X.; Zou, H. Identification of a Pseudomonas putida as biocontrol agent for tomato bacterial wilt disease. Biol. Control. 2017, 114, 45-50. [CrossRef]

28. Lopes, D.B.; Berger, R.D. The effects of rust and anthracnose on the photosynthetic competence of diseased bean leaves. Phytopathology 2001, 91, 212-220. [CrossRef]

29. Li, L.; Mohamad, O.A.A.; Ma, J.; Friel, A.D.; Su, Y.; Wang, Y.; Musa, Z.; Liu, Y.; Hedlund, B.P.; Li, W. Synergistic plant-microbe interactions between endophytic bacterial communities and the medicinal plant Glycyrrhiza uralensis F. Antonie Leeuwenhoek 2018, 111, 1735-1748. [CrossRef] [PubMed]

30. Abdelshafy, M.O.A.; Ma, J.-B.; Liu, Y.-H.; Zhang, D.; Hua, S.; Bhute, S.; Hedlund, B.P.; Li, W.-J.; Li, L. Beneficial endophytic bacterial populations associated with medicinal plant Thymus vulgaris alleviate salt stress and confer resistance to Fusarium oxysporum. Front. Plant Sci. 2020, 11. [CrossRef]

31. Garrity, G.; Brenner, D.J.; Krieg, N.R.; Staley, J.R. Bergey's Manual®of Systematic Bacteriology: Volume 2: The Proteobacteria, Part B: The Gammaproteobacteria; Springer: New York, NY, USA, 2007.

32. Li, H.; Zhao, J.; Feng, H.; Huang, L.; Kang, Z. Biological control of wheat stripe rust by an endophytic Bacillus subtilis strain E1R-j in greenhouse and field trials. Crop Protect. 2013, 43, 201-206. [CrossRef]

33. Chen, J.-P.; Lee, M.-S. Simultaneous production and partition of chitinase during growth of Serratia marcescens in an aqueous two-phase system. Biotechnol. Tech. 1994, 8, 783-788. [CrossRef] 
34. El-Tarabily, K.A. An endophytic chitinase-producing isolate of Actinoplanes missouriensis, with potential for biological control of root rot of lupin caused by Plectosporium tabacinum. Aust. J. Bot. 2003, 51, 257-266. [CrossRef]

35. Miller, G.L. Use of dinitrosalicylic acid reagent for determination of reducing sugar. Anal. Chem. 1959, 31, 426-428. [CrossRef]

36. Palanivel, P.; Ashokkumar, L.; Balagurunathan, R. Production, purification and fibrinolytic characterization of alkaline protease from extremophilic soil fungi. Int. J. Pharma Bio Sci. 2013, 4, 101-110.

37. Folin, O.; Ciocalteu, V. On tyrosine and tryptophane determinations in proteins. J. Biol. Chem. 1927, 73, 627-650. [CrossRef]

38. Pereira, M.G.; Vici, A.C.; Facchini, F.D.A.; Tristão, A.P.; Cursino-Santos, J.R.; Sanches, P.R.; Jorge, J.A.; Polizeli, M.d.L.T.d.M. Screening of filamentous fungi for lipase production: Hypocrea pseudokoningii a new producer with a high biotechnological potential. Biocatal. Biotransform. 2014, 32, 74-83. [CrossRef]

39. Prazeres, J.N.d.; Cruz, J.A.B.; Pastore, G.M. Characterization of alkaline lipase from Fusarium oxysporum and the effect of different surfactants and detergents on the enzyme activity. Braz. J. Microbiol. 2006, 37, 505-509. [CrossRef]

40. Lowry, O.H.; Rosebrough, N.J.; Farr, A.L.; Randall, R.J. Protein measurement with the Folin phenol reagent. J. Biol. Chem. 1951, 193, 265-275. [CrossRef]

41. Sackston, W. Studies on sunflower rust: II. Longevity of urediospores of Puccinia helianthi. Can. J. Bot. 1960, 38, 883-889. [CrossRef]

42. McInroy, J.A.; Kloepper, J.W. Survey of indigenous bacterial endophytes from cotton and sweet corn. Plant Soil 1995, 173, 337-342. [CrossRef]

43. Gardner, J.M.; Feldman, A.W.; Zablotowicz, R.M. Identity and behavior of xylem-residing bacteria in rough lemon roots of Florida citrus trees. Appl. Environ. Microbiol. 1982, 43, 1335-1342. [CrossRef] [PubMed]

44. Jacobs, M.J.; Bugbee, W.M.; Gabrielson, D.A. Enumeration, location, and characterization of endophytic bacteria within sugar beet roots. Can. J. Bot. 1985, 63, 1262-1265. [CrossRef]

45. Pang, F.; Wang, T.; Zhao, C.; Tao, A.; Yu, Z.; Huang, S.; Yu, G. Novel bacterial endophytes isolated from winter wheat plants as biocontrol agent against stripe rust of wheat. BioControl 2016, 61, 207-219. [CrossRef]

46. Kumar, A.; Singh, R.; Yadav, A.; Giri, D.; Singh, P.; Pandey, K.D. Isolation and characterization of bacterial endophytes of Curcuma longa L. 3 Biotech 2016, 6, 60. [CrossRef] [PubMed]

47. Tao, A.; Pang, F.; Huang, S.; Yu, G.; Li, B.; Wang, T. Characterisation of endophytic Bacillus thuringiensis strains isolated from wheat plants as biocontrol agents against wheat flag smut. Biocontrol Sci. Technol. 2014, 24, 901-924. [CrossRef]

48. Abeysinghe, S. Induced systemic resistance (ISR) in bean (Phaseolus vulgaris L.) mediated by rhizobacteria against bean rust caused by Uromyces appendiculatus under greenhouse and field conditions. Arch. Phytopathol. Plant Prot. 2009, 42, $1079-1087$. [CrossRef]

49. Haddad, F.; Saraiva, R.M.; Mizubuti, E.S.; Romeiro, R.S.; Maffia, L.A. Antifungal compounds as a mechanism to control Hemileia vastatrix by antagonistic bacteria. Trop. Plant Pathol. 2013, 38, 398-405. [CrossRef]

50. Vieira, A.; Talhinhas, P.; Loureiro, A.; Duplessis, S.; Fernandez, D.; Do Céu Silva, M.; Paulo, O.S.; Azinheira, H.G. Validation of RT-qPCR reference genes for in planta expression studies in Hemileia vastatrix, the causal agent of coffee leaf rust. Fungal Biol. 2011, 115, 891-901. [CrossRef]

51. Weller, D.M.; Mavrodi, D.V.; Van Pelt, J.A.; Pieterse, C.M.; Van Loon, L.C.; Bakker, P.A. Induced systemic resistance in Arabidopsis thaliana against Pseudomonas syringae pv. tomato by 2, 4-diacetylphloroglucinol-producing Pseudomonas fluorescens. Phytopathology 2012, 102, 403-412. [CrossRef]

52. Rajendran, L.; Samiyappan, R. Endophytic Bacillus species confer increased resistance in cotton against damping off disease caused by Rhizoctonia solani. Plant Pathol. J. 2008, 7, 1-12. [CrossRef]

53. Vinayarani, G.; Prakash, H. Growth promoting rhizospheric and endophytic bacteria from Curcuma longa L. as biocontrol agents against rhizome rot and leaf blight diseases. Plant Pathol. J. 2018, 34, 218. [CrossRef] [PubMed]

54. El-Deeb, B.; Bazaid, S.; Gherbawy, Y.; Elhariry, H. Characterization of endophytic bacteria associated with rose plant (Rosa damascena trigintipeta) during flowering stage and their plant growth promoting traits. J. Plant Interact. 2012, 7, 248-253. [CrossRef]

55. Castro, R.A.; Quecine, M.C.; Lacava, P.T.; Batista, B.D.; Luvizotto, D.M.; Marcon, J.; Ferreira, A.; Melo, I.S.; Azevedo, J.L. Isolation and enzyme bioprospection of endophytic bacteria associated with plants of Brazilian mangrove ecosystem. SpringerPlus 2014, 3, 382. [CrossRef]

56. Glick, B.R. Plant growth-promoting bacteria: Mechanisms and applications. Scientifica 2012, 2012, 963401. [CrossRef] [PubMed]

57. Ryan, R.P.; Monchy, S.; Cardinale, M.; Taghavi, S.; Crossman, L.; Avison, M.B.; Berg, G.; Van Der Lelie, D.; Dow, J.M. The versatility and adaptation of bacteria from the genus Stenotrophomonas. Nat. Rev. Microbiol. 2009, 7, 514-525. [CrossRef] [PubMed]

58. Hallmann, J.; Quadt-Hallmann, A.; Mahaffee, W.; Kloepper, J. Bacterial endophytes in agricultural crops. Can. J. Microbiol. 1997, 43, 895-914. [CrossRef]

59. Prasom, P.; Sikhao, P.; Koohakan, P. In vitro study of endophytic bacteria isolated from tomato plant against Fusarium oxysporum. Int. J. Agric. Technol. 2017, 13, 1217-1230.

60. Fouda, A.; Eid, A.M.; Elsaied, A.; El-Belely, E.F.; Barghoth, M.G.; Azab, E.; Gobouri, A.A.; Hassan, S.E.-D. Plant growth-promoting endophytic bacterial community inhabiting the leaves of Pulicaria incisa (Lam.) DC inherent to arid regions. Plants 2021, 10, 76. [CrossRef] [PubMed] 